\title{
MEMES AS MARKERS OF FAKES \\ AND PROPAGANDA TOPICS IN MEDIA REPRESENTATIONS OF THE RUSSIAN-UKRAINIAN CONFLICT
}

The article deals with memes as expressive rhetorical resource in media representations of the Russian-Ukrainian hybrid war and military conflict. It explores textual slogans of Russian propaganda that serve to legitimize external aggression. When these units are mirrored as intertextual material in the Ukrainian counter-discourse, they become critical targets for deconstructing fakes and decontamination of manipulative programs. The network of memetic signs is subordinated to the task of symbolic identification of conflict sides and their objectives.

Thematic groups of memes, referring to the scenario of military confrontation, reproduce senses of the main "battles for meaning" and the key narratives of the RussianUkrainian information warfare. The memetic markers give an opportunity to analyze such basic strategies of Russian propaganda as justification of aggression through appeal to historical myths, falsification of the meaning of the conflict and programs aimed at the protection of Ukraine's sovereignty, concealment of facts about the real perpetrators of aggression and origin of weapons, and spread of the threat formulas for intimidation of potential partners.

In the counter-discourse of Ukrainian media, fragments of the speech referring to the opposite side in ideological and military confrontation are presented with the accompaniment of figurative and factual means of distancing and rejection. The reconstructive strategies of Ukrainian media in relation to propaganda formulas are based on the use of factual information, in particular personal stories told by witnesses of events, investigative material, statistical data, and documents. The counter-frames, or interpretive frameworks of the Ukrainian mass media, work to substantially deny primary content of the propaganda "source".

Key words: propaganda, information war, meme, frame, script, strategy, rhetoric, intertextuality, fake, misinformation, counter-discourse.

Людмила Павлюк

канд. філол. наук, доц.,

Львівський національний університет

імені Івана Франка

\section{МЕМИ ЯК МАРКЕРИ ФЕЙКІВ \\ І ПРОПАГАНДИСТСЬКИХ ТОПІКІВ У МЕДІЙНИХ РЕПРЕЗЕНТАЦІЯХ РОСІЙСЬКО-УКРАЇНСЬКОГО КОНФЛІКТУ}

Досліджено меми як експресивний риторичний ресурс у мас-медійних репрезентаціях російсько-української гібридної війни. Об'єктом розгляду є гасла й мікроцитати із 
дискурсу російської пропаганди, що слугують для легітимації зовнішньої агресії та окупаційної політики РФ. Віддзеркалені в українському контрдискурсі як інтертекстуальний матеріал, вони використовуються у функції критичних мішеней-референцій для деконструкції фейків та знешкодження маніпулятивних програм. Загалом мережі меметичних знаків підпорядковані завданням символічної ідентифікації сторін конфлікту та їхніх завдань.

Тематичні групи мемів, виокремлені на основі фрейму - сценарію воснного протистояння, відтворюють сенси головних “битв за значення" та ключових наративів російсько-української інформаційної війни. Меметичні маркери дають змогу проаналізувати такі основні стратегії російської пропаганди, як виправдання агресії через апеляцію до історичних міфів, фальсифікація сенсу конфлікту та програм захисту суверенітету України, приховування фактів про реальних виконавців агресії та походження озброснь, поширення формул загрози та залякування потенційних партнерів.

У контекстах контрдискурсу украӥнських медіа фрагменти мовлення ідеологічного й воєнного супротивника не можуть бути подані інакше, аніж у супроводі фігуральних та фактологічних засобів заперечення й викриття. Викривальні стратегії українських авторів у стосунку до пропагандистських формул грунтуються на залученні фактичної інформації, зокрема особистих історій свідків подій, даних розслідувань, статистичного матеріалу та документів. Контрфрейми, тобто інтерпретативні межі української мас-медійної аналітики, працюють на те, щоб обгрунтовано заперечити первинний зміст пропагандистського “джерела".

Ключові слова: пропаганда, інформаційна війна, мем, фрейм, сценарій, стратегії, риторика, інтертекстуальність, фейк, евфемізми, дезінформація, контрдискурс.

1. An expressive sign for taking sides: meme and its persuasive properties. Any type of memes fulfills similar tasks. The opposite is also true: common tasks make a group of memes a separate specific type. For example, in popular culture memes aim at satisfying entertainment and aesthetic demands of the audience. A meme and propaganda have concluded contract on a basis of joint function and purpose of influence. The word "meme" exposes the same direct connection with persuasive uses of language as the concepts of "ideologeme" (an idiom embodying ideological belief), "mythologeme" ("a core element" of myth), "strategeme" (a verbal indicator of a determined course in politics or military). All these notions imply the use of catchy powerful words and images for delivery of relevant senses to target audiences.

Меме as a unit of information and communication possesses all the properties that are necessary for effective propaganda performances in media: 1) expressiveness, i. e. ability to concentrate and transmit emotions; 2) modern neologic nature and popular anti-official form; 3) reactivity as an imminent reaction to actual social events and resonating with the dynamics of their coverage in media; 4) interactivity, i. e. serving as object for comments in public dialogue and intermediary in interdiscursive transformations; 5) viralability as a capacity for rapid dissemination of information and energy in wide circles.

The authors of articles in modern periodicals and online journals habitually write about "weaponizing meme for political propaganda" [1]. The view of meme as a means of making sense and a persuasive media resource in scholarly discourse [2] coexists with more specified approach to this "unit of replication" as an instrument for waging hybrid wars in the analysis of internal and international conflicts. In particular, the "science of meme" was enhanced by the practically focused publications on "memetic wars" that were part of the research on strategic communication in combat operations [3]. The notion of memetic warfare highlights a distinctive way of expressing positions in the course of conflict, identification, and rhetorical interchange, which is typical for the epoch of social media.

Either we use terms "information war," "propaganda," or "hybrid war" (each of them has its own specifics) regarding the corpus of confrontational texts surrounding Russia-Ukraine political and military conflict, the media coverage of the warfare provides a vast material for the study of meme as "cognitive weapons" [4]. "It began in Ukraine" [4], rightfully remarks Timothy Thomas, describing Russia's focus 
on "the creation of 'alternative or new reality" in representation of Ukrainian politics, in particular postMaidan developments. Providing misinformation, Russian propaganda tries to shape perceptions and actions locally and globally and competes with West for impact on the international order. Headlines type of "Facebook Deletes Pages That Were Secretly Controlled by a Russian Propaganda Network" [5] signal about continuing resistance of the international community to the spread of Russian destabilizing influence worldwide.

"The alternarive truths" spread by Russian media are basically about the interference with multiple conflicts worldwide. For an average Ukrainian the notion of propaganda evokes the image of statesponsored Russian media and its personalities. This propagandistic pool, represented by professional proponents of ideology on TV, spin-doctors, trolls, and the "supporting" bloggers, has become a distributor of strategically loaded images and slogans that become a substrate for memes. The recognizable clichés in their discourse are aimed at consolidating the Us-group ("the Russian spring", "Iscanders laugh") and discrediting members of pro-Ukrainian group ("Ukraine is not a state", "the bloody junta" etc). However, it is one case when a consumer of these ideological constructions and references is an internal audience, and a completely different thing when the expressive filters for perception are targeted for a group that propaganda rhetoric tries to demoralize. Here, in fact, the work begins for Ukrainian counter-propaganda discourse - to neutralize harmful and hostile formulas imposed by the adversary.

2. Propagandistic database: stories behind memes of the Russian-Ukrainian information war. Rhetorical elements used as basic textual material for memes in the conflict-related public debate differ in origin: these can be slogans from an official propaganda campaign in media, more or less spontaneous phrases from comments of TV hosts and state officials, "fragments" of the fake news stories attempting to conceal crimes, or "slips of the tongue" that the interpreters choose for the symbolic mission. Regardless of whether a meme is originally a constructed formula, intended for public dissemination, or a "slice" of improvised argument that was "picked up from the flow" while not being purposefully created "for sale", in fact there are two authors for a meme. The first one is the author of a source text (or a figurant of event) and the second is an interpreter who attaches new context for revisiting and reframing the basic view encapsulated in an original formula. Below we will analyze origin of some key idioms underlying propaganda narrative about Russia's policies directed at Ukraine.

The cliché "Russian spring" emerged as a sign of Russian ideological expansion and call for unfolding "people's movements" in support of RF during annexation of Crimea and beginning of clashes in Donbas. This slogan is actually a metaphoric amplifier for the project called "Novorossiya", which inspired actions aimed at supporting agents of Russian administration and protesting against Ukrainian authorities in south-east regions. According to online sources, the term "Russian spring" was created, by analogy with the "Arab Spring", by Russian blogger Yehor Kholmogorov. This author, expressing an unambiguous view of Ukraine as enemy, and of Donetsk, Kharkiv and Odesa as material for joining with Moscow, called in February 2014: "Russian spring has already begun, and it's time to sincerely support it" [6].

It is noteworthy that a series of "mobilization" memes such as "the Russian spring", "Novorossiya" and "the Russian world" appeared in initial phase of the conflict simultaneously with discursive formula having a distinctive function of "frightening" the opponents. The target audience of these verbal repellants had to be Ukrainians and potential partners of Ukraine, who lacked "sincere" enthusiasm for understanding the events of the "Russian spring", and therefore, needed to be "warned". A professional TV propaganda person Dmitry Kiselev had created a vivid image of the Kremlin ideology when he spoke about turning the United States into "radioactive ash".

The meme "Iskanders laugh" is a phraseological trace that remained in the conflict-concerned public space after the all-Russian campaign of aggressive bluffing in response to introducing the first sanctions against Russia. "Sanctions? Do not make my Iskanders laugh", "Topol is not afraid of sanctions", read the "patriotic" inscriptions on T-shirts distributed during a "fashion action," inspired by "the commercial success of T-shirts depicting Putin" [6]. The event was supported by the Russian Duma official and some pop stars, in the role of models wearing the "Iskander" cloths. As a desirable outcome, 
citizens were expected to feel enthusiastic about Russia's "toughness" and perceive "Iskander" and "Topol", the long-range missiles, as most powerful argument in debate over international law.

The meme "stones from the sky" is yet another example of a massive, though less personalized campaign calling population of the occupied territories for loyal perception of the new order at the peninsula. It appeared following the first publicly expressed signs of uncertainty, such as slogan "The Crimean Spring ...What's next?" on billboards and city-lights in Sevastopol in 2014. To oppose this contemplative motto that was perceived as a starter of discontent campaign, guards of the regime placed "alternative" billboards with the lines of suggested "canonic" answer on the stripes of tricolor: "What's next?.. Let it even stones fall from the sky. We are in our motherland". Later on, this slogan became a reference metaphor for critics of the occupation authorities in numerous publications about the arbitrariness of self-proclaimed owners of the peninsula and the lost illusions of many inhabitants.

Another practical way of expanding the repertoire of memes that identify propagandistic "picture of the world" is to select elements indicative of the rhetorical falsification from a stream of broadcasted public communication. The speech of Russian politicians and leaders of illegal structures in the occupied territories provide samples of the propagandistic "canon", which are, however, questioned and reflected with the sign of irony in Ukrainian counter-discourse. In particular, the intertextual material of Ukrainian media includes indices of fake stories on the participation of Russian military in annexation of Crimea and in armed actions in Donbas: "ikhtamnet", "vacationers", "equipment from the local military trade", and "weapons from mines". For each of these memes of information warfare there is a separate story, although all together they form a single stylistic series.

The words "ikhtamnet" ("they are not there"), a meme that Ukrainian media uses mainly as barbarism ("іхтамнєт"), imitating pronunciation in the source language ("их там нет" / "ikh tam niet"), symbolizes Russian tactics of concealing information about events of undeclared war and the role of Russian military without signs of recognition in it. At a press conference on March 4, 2014, answering questions about members of the formation that captured Crimea - "So, were they Russian soldiers or not?" Putin said that the Russians were not involved in blocking units of the Ukrainian army: "These were local forces of self-defense" [7]. From the dialogues of the same press conference comes an ironic phrase about "equipment from military trade store (Voentorg PX)". To one listener's remark that groups of servicemen at the time of annexation were dressed in a form "very similar to Russian", Putin replied that such uniform is available in "all areas of the CIS": "Go to the store and you will buy any such a form" [7]. Distributed later in numerous comments, the image of "military cloths trade" has become a symbol of all the rhetorical "encryptions" and evasive responses about the origin of weapons of militants in Donbas.

"People on leave" ("the vacationers") is an ironic (in the Ukrainian discourse) name of Russian military personnel, soldiers and officers who fight against the Ukrainian army in Donbas. This expression was used by the former "minister" of the so-called "Donetsk People's Republic", colonel Ihor Girkin (Strelkov), describing the role of groups of military forces from Russia who arrived in the east of Ukraine, in exacerbating the situation (his people "began to fight seriously") and the expansion of the front in the summer of 2014. The former head of the "DPR" O. Zakharchenko made this rhetorical catch-word even more familiar, as he pathetically explained the motives of Russian "liberators" in an interview with Channel Russia 24: "Many Russian servicemen came here, preferring not to head for the sea coast, and joined the ranks of their brothers who are fighting for the freedom of the Donbas" [6].

In many occasions memes signal about awkward or completely failed attempts of propaganda to save reputation of characters involved in criminal cases. The justifying formulas used for this purpose acquire anecdotal shades, because their "bleaching" function is too contrasted with the reality of negative occurences. The media, undertaking reconstruction of fake stories, step by step, that is, with every discursive repetition, transform the details of criminal cases into symbols. These can be, for instance, names of perpetrators of scandals or metonymic references to crime scenes, such as "Petrov" and "Boshirov" (fake names of guys who arrived from Russia in Great Britain with assassination mission), "Salisbury spiers" (lies about visiting cultural sites told to justify presence in the city where the crime was committed), "aerodrome controller Carlos" (referring to story about the fake witness from airport in Spain providing false evidence in Russia's favor about the MH17 crash). Memes of this type are "extracted" from 
propaganda narratives, which are not simply designed to reclaim ideological values, but are fabricated as "legends" to cover the terrorist and liquidation operations.

3. Main themes and functions of memes within the macro-frame of conflict. In the discourse of propaganda during war, as in any other variety of texts, linguistic tools become equivalent of practical action. The components of Russian ideological narrative have a direct function to divert attention from the topic of responsibility for crimes and transfer guilt to the Ukrainian side. In the mirror of Ukrainian public discourse, micro-quotes from the language of Russian propaganda become memetic indices that identify fake and ideologically false signs and arguments of the opposite textual field.

The micro-quotes exposed below show thematic branches of the propaganda "arguments" that cover crimes of Russian political and military leadership in Crimea and occupied Donbas. The scenarios for both regions are considered separately (individually) and are represented by set of typical frames indicative of each scene of conflict. It is obvious that the original authorship of each phrase (or event producing the reference) belongs to Russian sources, while Ukrainian media use them as reflective screen and objects for critical perception, i. e. not as co-opted appeal, but on the contrary - as rejected ideas:

1) The frame "intervention in Crimea and annexation" includes a network of symbolic expressions that refer to a number of events and beliefs: a) legitimation of aggression and annexation through historical myths: "the clamps" (image of shared values gluing Russian communities and implying the need to protect them anywhere ("protection of Russian-speaking citizens"), "the city of Russian glory" (paraphrase for Sevastopol), "the Russian world"; b) incentives for actions and slogans of ideological consolidation: "Crimea is ours," "the Russian spring", "referendum for self-determination of the local population", "let even stones drop from the sky"; c) compromising Ukraine and diminishing its right to protect sovereignty; reframing causes of the interstate conflict: "Ukraine is not a state", "the civil conflict"; "coup d'état in Kyiv" (the Russian official interpretation of the Revolution of Dignity and postMaidan developments); d) fake images of threats allegedly coming from Ukraine: "the trains of friendship", "Yarosh's card", (mentioning leader of Right Sector), "Crimean saboteurs" (fabricated stories about of radical groups and persons purportedly threatening population in Crimea); e) legitimization and embellishment of the perpetrators of aggression: "ikhtamnet", "polite people", "green men"; f) formulas of intimidation and reminding of threats: "Iskanders laugh", "nuclear ashes."

2) The frame "occupation of Donbas" includes the following repeating themes and motifs: a) motivational and mobilization slogans for inducing pro-Russian ideological position: "the Russian spring", "the Russian world", "Novorossiya"; b) hyperbolic accusative images of Ukraine's defense strategies: "bloody junta", "punitive actions"; c) falsification of the meaning of conflict: "it is civil war", "the internal affair of Ukraine"; d) performers of military actions: "ikhtamnet", "vacationers"; e) the origin of weapons: "from the local mil-trade store", "weapons from mines"; f) reminders about threats: "we can repeat it," "they will die, while we go to heaven".

Deconstruction of a fake is a repetitious procedure that involves appearance and further reiteration of new visual and verbal details of basic narrative. Besides, each individual meme constantly undergoes change in form and emerges in the ever new environment, the micro-context. Sufficient recognition allows the meme to function in a number of transformed variants. Numerous modifications of an original primary story in their turn serve as an indicator of the relevance of a topic, as well as its contextual adaptability. By performing function of symbolic identification, meme forms a content matrix for the analogous scripts.

For example, the term "ikhtamnet," used in multiple contexts, shows the typicality of Russian policy of armed expansion in many locations of the world, in particular for the promotion of dictatorial regimes. Here are some media examples of such changes in the form and content of "primary" meme "ikhtamnet" that are used to show the extended geography of Russian interference: "the Syrian "ikhtamnet"; "from Moscow to Venezuela, a mysterious plane carried 500 obscure "ikhtamnet"; "Russian "ikhtamnet" are going to the Caribbean". A variety of versions emphasize the common logic of many events, separated in space and time. 
4. Counter-framing and its factual points in the Ukrainian media discourse. As it was remarked earlier, peculiarity of the persuasive cliché of information warfare is that meme is a result of two opposite interests -1 ) the attention of a "native" audience to a phrase or character, and 2) interpretation of the opponents. In many cases, it is the same expression or image, both in language of propaganda and in the counter- discourse, only with different appraisal marks and in diverging perceptual contexts. The counterframes, correspondingly, work to substantially deny the original meaning of the "source".

A principal way for the Ukrainian media to sustain meanings matching with doctrine of national sovereignty and self-defense is to show the contrast between strategies and pictures of life that are claimed in propaganda script and those that are perceived as real, objective, and adequate. Below are described examples of several thematic groups of memes, content of which is disclosed and exposed by means of factual information, such as personal stories, investigative data, statistical material, and documents.

The meme "polite people", tightly associated with the scenario of annexation of Crimea in 2014, appeared as euphemistic answer to serious investigative question "Who committed this dashing brutal act?" In order to construct the image of annexation as a proper operation, Russian propaganda resorted to the description "polite people" while denoting the Russian military who ensured transition to the occupation regime. It bluntly makes emphasis on non-existing "courtesy", in contrast to the Ukrainian view of these people as militants undertaking illegal, terrorist activities. Many foreign media in spring of 2014 were inclined to repeat the phrase about "polite people", because, receiving information from Russian sources, they learned the proposed phraseology. However, the borrowed cliché often showed up in contrast with recognition of brutality of the action and was moderated by the expressed doubt regarding its appropriateness.

The authors writing for Ukrainian media preferred more neutral metonymic name "green men" to "polite peopl"e. While "green men" is simply ironical, the expression "polite people" can be only used with utter sarcasm, because it is an inappropriate mockery of tragedy and crime. The real stories by witnesses of occupation show that "polite people" in reality were people with weapons, who did not hesitate to suppress resistance and were ready to "shoot from behind the shoulders of women and children", according to famous Putin's warning and comment that turned into another meme belonging to group of the "threat markers". The witnesses of the spring 2014 events, judge from Crimea, recalls how anonymous "people" reacted to his refusal to remove Ukrainian flag from the office building: "Suddenly, at some point, one from the crowd of these "green men" unexpectedly hit me with a rifle butt in the jaw. Knocked out four teeth to me. I did not understand this at once, because the mouth was immediately filled with blood..." [8]. Such cases for inducing loyalty by force had nothing to do with the invented meme mentioning "politeness".

Discursive materialization of "ikhtamnet" ("they are not there") usually looks like facts supporting statement "they are there". The phrase "ikhtamnet", which in fact became not only the "specie" name of the Russian military personnel without signs of recognition, but also, much wider, an indication of misleading strategies for justifying aggression. The counter-discourse of the Ukrainian side, refuting the "ikhtamnet" approach, emphasizes facts, including statements of people escaped from captivity, evidence of the death of militants, identified by documents as citizens of Russia, monuments in the territory of Russia to Russians who died in Ukraine. "Why are these Russians killed in Donbas, where they do not exist?" (or: "Why do the monuments to Russian liberators of Donbas, Russian volunteers, open all over Russia? What did they liberate if they were not there?") [9]

Definitions of the Russian side as an attacker and direct participant of military actions in Ukraine and worldwide are based on journalistic reports and analysis of military personnel acting in foreign countries on behalf of Russian interests. Politics in the style of "Syria is ours" (a transformation of the meme "Krymnash", "Crimea is ours") prompted a need for propaganda "hide" coverage of the Russian "ikhtamnet" (military presence) in Syria. The usual secrecy, to which Russian military resorted instead of informing Americans during an offensive for a raider capture of oil refinery, became the reason for many casualties among Russian military. Based on context of this operation, media provided a lot of investigative materials on the activities of Russian units abroad: "PJC Wagner" is a disguised name of the most combat-capable Russian units in Syria, the so-called "ikhtamnet." These are the detachments of 
special operations forces, which until then actively fought in Ukraine, and now in Syria. Before the offensive, the Russian military from these units will hand over their passports and military tickets..." [10].

The euphemistic name "vacationers," depicting participants of the armed conflict from Russia as private individuals who arrived in Donbas for something that might seem almost as "hobby" and leisure time, actually concerned people who served in the region as military "advisers", "curators", and just killers. The documented facts of the Russian military presence shed light on circumstances of many resonant crimes. Among those who were identified as involved in the Boeing 777 crash, there was a "vacationer" with nickname Orion, the Russian GRU commander Oleg Ivannikov, responsible for transportation of the missile launch facility "Buk" to Ukraine and its return to Russia, and also a military "advisor" and "curator" of the political leadership of "LNR" in 2014, Tkachev-"Dolphin", whose task was to "sculpture out from an amorphous pool of detachments more or less an army structure in "LNR" [11]. This function after the departure of Tkachev was taken by another "vacationer," Russian major-general Sergey Kuzovlev, who became "the commander of the 1st Army Corps of Russian Armed Forces in an armed conflict in east Ukraine" [11]. The formations known as the first and second corps under the control of Russian generals is the actual case of troops organization in Donbas, which shows real meaning of the related fake paraphrases. The well-known "ikhtamnet" are really active armed formations, military corps led by Russian servicemen.

In a phase of direct armed confrontation during interstate conflict, information tools become heavily involved in the conduct of military campaigns, which often means that an object of military aggression is simultaneously the target of propaganda. Using strategies of disinformation, embodied, among other means, in memes, media of the occupying state divert attention from its own massive involvement in military actions, falsify sence of processes taking place in the attacked state, show threats as coming from Ukrainian side, and consolidate pro-Russian ideological position.

For Ukraine, the factual evidence-based approach confirms the definition of the Russian side as attacker and principal participant of the military conflict, and also explains the reasons for Ukraine's basic understanding of the conflict as interstate and opposed to "civil" one. The authors of media texts devoted to the analysis of military and ideological confrontation aim at demonstrating that the facts of existential world are on the side of "We-group", the pro-Ukrainian forces. Checking a "primary" story with available data, they expose contrast between the propaganda scenario and a real state of affairs.

In the information war, surrounding Russia-Ukrainian military conflict and geopolitical stand-off, memes serve as a means of mapping identities, stating beliefs, and developing strategies. A whole corpus of recognizable, expressive, and memorable clichés that originate in Russian media, in the Ukrainian public discourse is used within new contexts that question their original sense and reconstruct the "twosided" balance in the observations of the war scenario. Finally, memes in counter-discourse become an instrument for identifying fakes and manipulative behaviors and are analyzed and re-interpreted in most substantial factual ways.

1. Olsen, D. (2018, January 24). How memes are being weaponized for political propaganda. Salon.com. Retrieved April 12, 2019, from https://www.salon.com/2018/02/24/how-memes-are-beingweaponized-for-political-propagandal [in English]. 2. Brodie, R. (2011). Virus of the Mind: The New Science of the Meme. Hay House Inc.[in English]. 3. Prosser, M. (2015). Memetics: A Growth Industry in US Military operations. CreateSpace Independent Publishing Platform. Retrieved April 25, 2019, from https://apps.dtic.mil/dtic/tr/fulltext/u2/a507172.pdf [in English]. 4. Thomas T. (2016). Russia's 21 century Information War: Working to Undermine and Destabilize Populations. Sstratcomcoe.org. Defense Strategic Communications, V. 1. Retrieved April 17, 2019, from https://www.stratcomcoe.org/timothythomas-russias-21st-century-information-war-working-undermine-and-destabilize-populations [in English]. 5. Novak, M. (2019, January 17). Facebook Deletes Pages That Were Secretly Controlled by a Russian Propaganda Network. Gizmodo.com. Retrieved May 15, 2019, from https://gizmodo .com/facebook-deletes-pages-that-were-secretly-controlled-by-1831830363 [in English]. 6. Матюхіна H., Бугоркова О. (11 квітня 2015). Криза в Україні у словах та виразах.Вbс.сот. https://www.bbc.com/ukrainian/politics/2015/04/150411_internet_wars_glossary_rl [in Ukrainian]; 
Адагамов Р. (24 сентября 2014). Не смешите мои Искандеры. Блог "Drugoi". http://kavpolit.com/blogs/drugoi/7295/ [in Russian]. 7. Доклад Немиова о войне РФ на Донбассе. Путин. Война. http://tsn.ua/special-projects/nemtsov/ [in Russian]. 8. Чайка И. (21 июня 2018). Предатели в Крыму уже поплатились за измену - судья-переселенец. Obozrevatel.com. https://www.obozrevatel.com/society/predateli-v-kryimu-uzhe-poplatilis-za-izmenu-sudya-pereselenets.htm [in Russian]. 9. Степова О. (16 февраля 2019). "Навоевались”, или “Почему эти русские убиты на Донбассе, где их нет”. Obozrevatel.com. www.obozrevatel.com/society/navoevalis-ili-pochemи-etirusskie-ubityi-na-donbasse-gde-ih-net.htm [in Russian]. 10. Шевчук В. (12 февраля 2018). Массовая гибель российских военных, или Что случилось в Сирии. Obozrevatel.com. https://www.obozrevatel.com/abroad/massovaya-gibel-rossijskih-voennyih-ili-chto-sluchilos-v-sirii.htm [in Russian]. 11. МН17: Російський командир ГРУ “Оріон” ідентифікований як Олег Іванников (Травень 26, 2018). Stopfake.org. https://www.stopfake.org/uk/mh17-rosijskyj-komandyr-gru-orionidentyfikovanyj-yak-oleg-ivannykov/[in Ukrainian].

\section{REFERENCES}

1. Olsen, D. (2018, January 24). How memes are being weaponized for political propaganda. Salon.com. Retrieved April 12, 2019, from https://www.salon.com/2018/02/24/how-memes-are-beingweaponized-for-political-propagandal [in English]. 2. Brodie, R. (2011). Virus of the Mind: The New Science of the Meme. Hay House Inc. [in English]. 3. Prosser, M. (2015). Memetics: A Growth Industry in US Military operations. CreateSpace Independent Publishing Platform. Retrieved April 25, 2019, from https://apps.dtic.mil/dtic/tr/fulltext/u2/a507172.pdf [in English]. 4. Thomas, T. (2016). Russia's 21 century Information War: Working to Undermine and Destabilize Populations. Sstratcomcoe.org. Defense Strategic Communications, Vol. 1 Retrieved April 17, 2019, from https://www.stratcomcoe.org/timothythomas-russias-21st-century-information-war-working-undermine-and-destabilize-populations [in English]. 5. Novak, M. (2019, January 17). Facebook Deletes Pages That Were Secretly Controlled by a Russian Propaganda Network. Gizmodo.com. Retrieved May 15, 2019, from https://gizmodo. com/facebook-deletes-pages-that-were-secretly-controlled-by-1831830363 [in English]. 6. Matiukhina, N., Bugorkova, O. (2015, April 11) Kryza v Ukrayini u slovakh ta vyrazakh [The crisis in Ukraine in words and phrases]. Bbc.com. Retrieved February 25, 2018,from https://www.bbc.com/ukrainian/ politics/2015/04/150411_internet_wars_glossary_rl [in Ukrainian]. 7. Doklad Nemtsova o voyne RF na Donbasse. Putin. Voyna. [Putin. War. Report by Nemtsov on the Russian war in Donbas]. Retrieved January 25, 2018, http://tsn.ua/special-projects/nemtsov/ [in Russian]. 8. Chayka, I. (2018, June 21). Predateli $v$ Krymu uzhe poplatilis' za izmenu - sud'ya-pereselenets. [Traitors in Crimea have already paid for treason - a displaced judge]. Obozrevatel.com. Retrieved March 22, 2018, from https://www.obozrevatel.com/society/predateli-v-kryimu-uzhe-poplatilis-za-izmenu-sudya-pereselenets.htm [in Russian]. 9. Stepova, O. (2019, February 16). "Navoyevalis", ili "Pochemu eti russkiye ubity na Donbasse, gde ikh net" [It's enough with that, or Why are these Russians killed in Donbas, where they are not]. Obozrevatel.com. Retrieved March 27, 2019, from www.obozrevatel.com/society/navoevalis-ilipochemu-eti-russkie-ubityi-na-donbasse-gde-ih-net.htm [in Russian]. 10. Shevchuk, V. (2018, February 18). Massovaya gibel' rossiyskikh voyennykh, ili Chto sluchilos'v Sirii [The mass death of the Russian military, or what happened in Syria]. Obozrevatel.com. Retrieved March 22, 2018, from https://www.obozrevatel.com/abroad/massovaya-gibel-rossijskih-voennyih-ili-chto-sluchilos-v-sirii.htm [in Russian]. 11. MH17: Rosiys'kyy komandyr HRU "Orion” identyfikovanyy yak Oleh Ivannykov. Traven' 26, 2018 Stopfake.org Traven£26, 2018 [MH17: The Russian commander of the GRU Orion is identified as Oleg Ivannikov. May 26, 2018] Retrieved May 17, 2019, from https://www.stopfake.org/uk/mh17rosijskyj-komandyr-gru-orion-identyfikovanyj-yak-oleg-ivannykov/ [in Ukrainian]. 